\title{
Newly developed microsatellite markers for the pan-European duck mussel, Anodonta anatina: revisiting the main mitochondrial lineages
}

\author{
MANUEL LOPES-LIMA ${ }^{\mathrm{a}, \mathrm{b}, *}$, RONALDO SOUSA $^{\mathrm{a}, \mathrm{c}}$, AMÍLCAR TEIXEIRA $^{\mathrm{d}}$, SIMONE VARANDAS ${ }^{\mathrm{e}}$, \\ NICOLETTA RICCARDI ${ }^{\mathrm{f}}$, DAVID C. ALDRIDGE ${ }^{\mathrm{g}}$ and ELSA FROUFE ${ }^{\mathrm{a}}$ \\ ${ }^{a}$ Interdisciplinary Centre of Marine and Environmental Research (CIIMAR/CIMAR), University of Porto, Porto, Portugal \\ ${ }^{\mathrm{b}} I U C N / S S C$ - Mollusc Specialist Group, c/o IUCN, Cambridge, UK \\ ${ }^{\mathrm{C}}$ CBMA - Centre of Molecular and Environmental Biology, Department of Biology, University of Minho, Braga, Portugal \\ ${ }^{\mathrm{d}}$ CIMO/ESA/IPB - Mountain Research Centre, School of Agriculture, Polytechnic Institute of Bragança, Bragança, Portugal \\ ${ }^{\mathrm{e}}$ CITAB/UTAD - Forestry Department, Centre for Research and Technology of Agro-Environment and Biological Sciences, University \\ of Trás-os-Montes and Alto Douro, Vila Real, Portugal \\ ${ }^{\mathrm{f}} \mathrm{CNR}$ - Institute for Ecosystems Studies, Verbania Pallanza (VB), Italy \\ ${ }^{\mathrm{g}}$ University of Cambridge, Aquatic Ecology Group, Department of Zoology, Cambridge, UK
}

\begin{abstract}
1. Freshwater mussels of the family Unionidae are one of the most threatened groups worldwide and have suffered severe decline over recent decades. Although the freshwater duck mussel, Anodonta anatina (Linnaeus, 1758), is still widespread, this species has shown evidence of recent declines and is already protected in some European countries.

2. Informed conservation efforts must take into account patterns in genetic diversity and phylogeography. In the present study, 20 newly developed polymorphic loci were described and tested in seven populations of $A$. anatina, belonging to three previously detected divergent mtDNA lineages. The genetic diversity patterns, within and among $A$. anatina populations, were evaluated to test their congruence with those lineages.

3. A high genetic differentiation $\left(F_{\mathrm{ST}}\right)$ was found among all populations, with the exception of those in Central Europe (Germany) and the UK, which were not strongly structured.

4. The present study confirms the division of the species into three evolutionarily significant units corresponding to the three previously detected mtDNA lineages, which should be managed independently. Furthermore, owing to the high differentiation among southern European populations, the establishment of distinct management units for the Guadalquivir, Guadiana and Douro populations in the Iberian Peninsula is also proposed.

Copyright (C) 2015 John Wiley \& Sons, Ltd.
\end{abstract}

Received 18 October 2014; Revised 17 March 2015; Accepted 27 April 2015

KEY WORDS: Anodonta anatina; anodontini; genetic diversity; microsatellites; Unionidae; conservation genetics

*Correspondence to: M. Lopes-Lima, Interdisciplinary Centre of Marine and Environmental Research (CIIMAR/CIMAR), University of Porto, Rua dos Bragas 289, 4050-123 Porto, Portugal. E-mail:lopeslima.ciimar@gmail.com 


\section{INTRODUCTION}

Freshwater bivalves of the order Unionoida, also known as freshwater mussels, are among the most threatened faunal groups worldwide (Strayer et al., 2004; Lopes-Lima et al., 2014). Unionoid mussels are widespread, colonizing freshwater ecosystems of all continents except Antarctica. They can attain very high densities in some habitats (Bogan, 2008) which, together with their filter-feeding behaviour, make them particularly important in the transfer of matter and energy from the water column to the benthos (Strayer et al., 1999). In addition, these bivalves are important ecosystem engineers (Gutiérrez et al., 2003), not only through the indirect effects of filter feeding (e.g. increasing water clarity), but also by bioturbation and consequent changes in the sediments (e.g. oxygen, organic matter, redox potential) and the production of shells, which function as a substrate for other species (Vaughn and Hakenkamp, 2001; Aldridge et al., 2007; Spooner et al., 2013). Unionoids also provide important services to humans, such as purification of water, as prey for several commercial fishes and as a source of food and other valuable materials (shells and pearls) (Haag, 2012).

Anodonta anatina (Linnaeus, 1758) is the most widespread freshwater mussel species in the Palaearctic, occurring from Portugal and the British Isles in the west to the Transbaikal region in the east of Russia (Douda et al., 2013; Hinzmann et al., 2013). Although this species is considered common and widespread in most countries, severe declines have been reported in some regions and consequentially this species is listed as Near Threatened or Threatened in Austria, Germany, Ireland and Romania (Sárkány-Kiss, 2003; Reischütz and Reischütz, 2007; Byrne et al., 2009; Binot-Hafke et al., 2011). However, the taxonomy of this species is still contentious, which may impair the application of possible conservation measures. Indeed, until the middle of the 20th century, many malacologists had split $A$. anatina into hundreds of regional species, mainly based on its highly variable shell characters (Graf, 2010). Nevertheless, by the end of the 20th century most of these synonymies had been resolved, merging all these putative species into A. anatina (Araujo, 2013).

Only recently has the genetic diversity of $A$. anatina been described across a large part of its entire range. Froufe et al. (2014) described the existence of at least three major mtDNA lineages in most of its European range, with non-overlapping geographic distributions and with significant genetic differences among them. One lineage includes all Atlantic Iberian populations, the second includes individuals from the Mediterranean Iberian Peninsula (Ebro) and Italy and the third includes the remaining European populations, from the British Isles in the west to Russia in the east. Furthermore, the results indicated that $A$. anatina has a pronounced genetic substructure within the Atlantic Iberian lineage, consistent with the existence of multiple Pleistocene refugia within this region (for a review see Gómez and Lunt, 2007). Since the mitochondrial DNA represents only the maternal lineage and its exclusive use may introduce errors in phylogenetic studies owing to phenomena such as hybridization and introgression (Alves et al., 2006), data from nuclear markers should be used to complement these results.

Microsatellite markers are ideal for inferring population structure and dynamics and have been used frequently in conservation genetics studies of freshwater mussels with many applications: for example, to understand the spatial patterns of genetic diversity, including isolation, gene flow and migration (Geist et al., 2010a; Mock et al., 2013); to establish phylogeographical patterns and the establishment of evolutionary and management units (Zanatta and Murphy, 2008); to establish co-evolution patterns between a freshwater mussel species and its host fish (Zanatta and Wilson, 2011); to investigate the occurrence and frequency of multiple paternity (Bai et al., 2012); and to investigate maximum fertilization distance among female and male freshwater mussels (Ferguson et al., 2013).

To date, microsatellite markers have been developed for few European freshwater mussel species, i.e. Margaritifera margaritifera (Linnaeus, 1758) (Geist et al., 2003), Unio crassus Philipsson, 1788 (Sell et al., 2013), Potomida littoralis (Cuvier, 1798) (Froufe et al., 2013) and Anodonta cygnea 
(Linnaeus, 1758) (Geist et al., 2010b). Moreover, with the exception of $M$. margaritifera (Geist and Kuehn, 2005; Bouza et al., 2007; Geist et al., 2010a), no conservation or phylogeographic studies using these markers have been published so far. Therefore, the present study aimed: (i) to develop effective and polymorphic microsatellite markers for $A$. anatina; (ii) to compare their usefulness in identifying discrete evolutionary and management units with lineages previously described by Froufe et al. (2014) using mtDNA; and (iii) to characterize the genetic diversity patterns of the species.

\section{METHODS}

\section{Specimens examined and DNA extraction}

Small samples from the foot were non-destructively excised (following Naimo et al., 1998) and placed directly into $99 \%$ ethanol, relocating the mussel back to its previous position. In total, $140 \mathrm{~A}$. anatina specimens were collected from seven different ecosystems (Figure 1, Table 1). Total genomic DNA was extracted from all individuals using a standard high-salt protocol following Sambrook et al. (1989).

\section{Microsatellite development}

Total genomic DNA from one A. anatina individual was sent to Genoscreen (Lille, France) for microsatellite-enriched library preparation and sequencing by 454 Genome Sequencer FLX Titanium (454, Roche Applied Science) using the method described by Malausa et al. (2011). Multiple sequences were received in FASTA format with the respective quality files. PCR reactions were

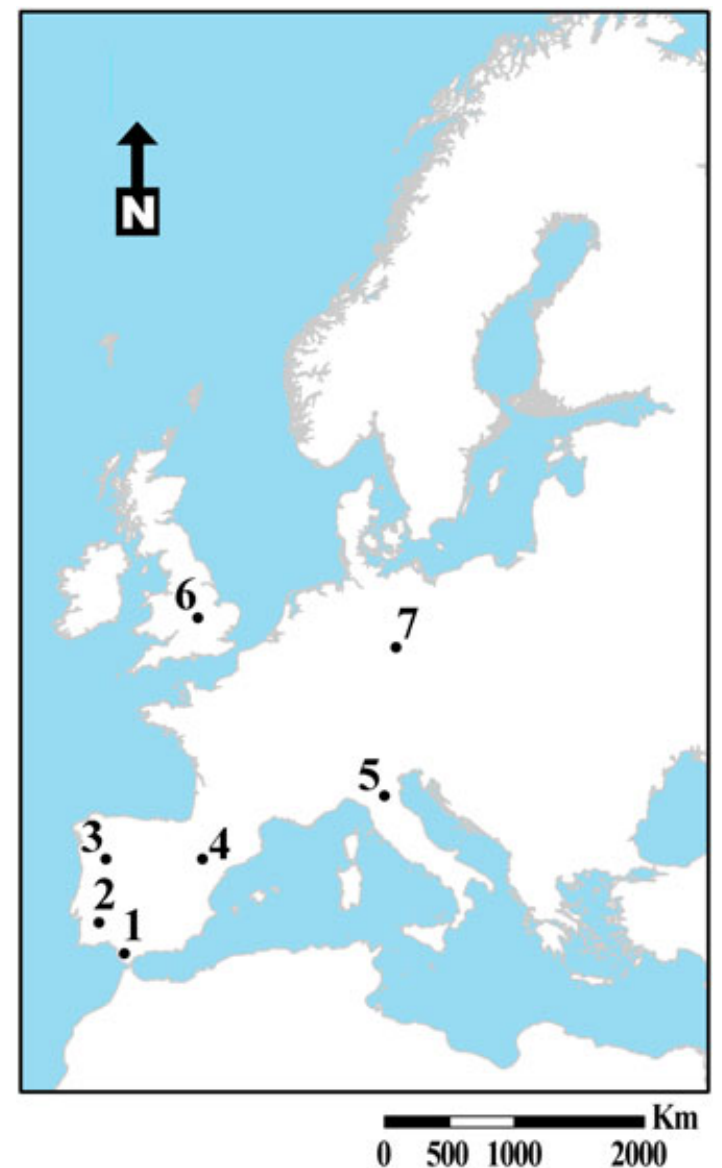

Figure 1. Map showing the locations of Anodonta anatina populations analysed with the microsatellite markers: 1 - Guadalquivir, 2 - Guadiana, 3 - Douro, 4 - Ebro, 5 - Reno, 6 - Medway, 7 - Rhine.

then designed to amplify the new loci to improve genotyping throughput as well as cost-effectiveness.

Four sets of nine primer pairs each were chosen and initially tested, following Froufe et al. (2013), on 21 individuals (three per population) with PCR reactions in simplex to validate selected loci and ascertain optimal annealing temperatures. After these trials, 20 loci were selected, combined in

Table 1. Location of the analysed Anodonta anatina populations and corresponding microsatellite statistics; $N=$ number of samples; $N_{\mathrm{A}}=$ number of observed alleles per population; $N_{P A}=$ number of private alleles per population; $H_{E}=$ mean expected heterozygosity; $H_{O}=$ mean observed heterozygosity; $F_{\mathrm{IS}}=$ mean inbreeding coefficient

\begin{tabular}{|c|c|c|c|c|c|c|c|c|c|c|}
\hline Population (basin) & Site & Latitude & Longitude & Country & $N$ & $N_{A}$ & $N_{P A}$ & $H_{E}$ & $H_{O}$ & $F_{\mathrm{IS}}$ \\
\hline Guadiana & River Oeiras & $37^{\circ} 36^{\prime} 43.83^{\prime \prime} \mathrm{N}$ & $7^{\circ} 49^{\prime} 53.76 " \mathrm{~W}$ & Portugal & 20 & 79 & 10 & 0.35 & 0.32 & 0.12 \\
\hline Ebro & River Ebro & $41^{\circ} 50^{\prime} 11.79^{\prime \prime} \mathrm{N}$ & $1^{\circ} 14^{\prime} 02.06^{\prime \prime} \mathrm{W}$ & Spain & 20 & 62 & 10 & 0.26 & 0.29 & 0.04 \\
\hline Reno & Lake Castel dell'Alpi & $44^{\circ} 11^{\prime} 06.98^{\prime \prime} \mathrm{N}$ & $11^{\circ} 16^{\prime} 34.19^{\prime \prime} \mathrm{E}$ & Italy & 20 & 114 & 34 & 0.52 & 0.43 & 0.19 \\
\hline Medway & River Medway & $51^{\circ} 24^{\prime} 48.43^{\prime \prime} \mathrm{N}$ & $0^{\circ} 42^{\prime} 20.16^{\prime \prime} \mathrm{E}$ & United Kingdom & 20 & 114 & 16 & 0.52 & 0.55 & -0.03 \\
\hline Rhine & Reinhardswinden pond & $49^{\circ} 58^{\prime} 31.49^{\prime \prime N}$ & $10^{\circ} 27^{\prime} 10.54^{\prime \prime E}$ & Germany & 20 & 123 & 17 & 0.58 & 0.58 & 0.03 \\
\hline
\end{tabular}


three multiplex-PCR reactions (eight in MixA, seven in MixB, and five in MixC; Table 2) and tested for polymorphism in all the $140 \mathrm{~A}$. anatina individuals. PCR reactions were performed on a DNA Engine DyadW Peltier Thermal Cycler (Bio-Rad Laboratories), consisting of a denaturing step at $95^{\circ} \mathrm{C}$ for $15 \mathrm{~min}$ followed by 11 cycles of denaturation at $95^{\circ} \mathrm{C}$ for $30 \mathrm{~s}, 90 \mathrm{~s}$ annealing at $58^{\circ} \mathrm{C}$ where the annealing temperature was lowered by $0.5^{\circ} \mathrm{C}$ with each consecutive cycle, and $30 \mathrm{~s}$ elongation at $72^{\circ} \mathrm{C} ; 29$ cycles of denaturation at $95^{\circ} \mathrm{C}$ for $30 \mathrm{~s}$, annealing at $53^{\circ} \mathrm{C}$ for $60 \mathrm{~s}$, and extension at $72^{\circ} \mathrm{C}$ for $30 \mathrm{~s}$; and a final extension at $60^{\circ} \mathrm{C}$ for $30 \mathrm{~min}$. Labelled PCR amplicons were resuspended in $10 \mathrm{~mL}$ Hi-DiTM Formamide and their sizes determined in an Applied Biosystems 3100 DNA analyser, with LIZ 500 size standard as an internal size standard.

\section{Microsatellite analyses}

In total, 140 individuals were genotyped for all 20 loci. Allele frequencies, observed $\left(\mathrm{H}_{\mathrm{O}}\right)$ and expected heterozygosity $\left(\mathrm{H}_{\mathrm{E}}\right)$, were estimated in Genetix v.4.0.5.2 (Belkhir et al., 2004). Linkage disequilibrium (LD), inbreeding coefficients $\left(F_{\mathrm{IS}}\right)$ and deviations from the Hardy-Weinberg equilibrium (HWE) were tested in Genepop-on-the-Web (http:// genepop.curtin.edu.au/index.html; Raymond and Rousset, 1995) using exact tests with significance estimated by a Markov chain method after 10000 randomizations. Sequential Bonferroni correction was employed to account for multiple testing (Holm, 1979). The presence and frequency of null alleles were tested in each locus using MICROCHECKER (Van Oosterhout et al., 2004) and FREENA (Chapuis and Estoup, 2007), respectively. Alleles were considered as private alleles if they exhibited a frequency of more than $5 \%$ in one population and did not occur in any other population.

Global, single-locus and pairwise genetic differentiation among samples and their putative genetic structuring were assessed with the $F_{\text {ST }}$ fixation index (Weir and Cockerham, 1984) in FSTAT 2.9.3.2 (Goudet, 1995), with significance being assessed with 1000 permutations. In addition, Jost's actual measure of differentiation $\mathrm{D}_{\text {est }}$ (Jost, 2008) was estimated using SMOGD v.1.2.5 (Crawford, 2010). The impact of null alleles was assessed by comparing $F_{\mathrm{ST}}$ estimates before and after correction for null alleles using the ENA (Excluding Null Alleles) method implemented in FREENA. As the null alleles had minimal or no impact on $F_{\mathrm{ST}}$ estimates (data not shown), all subsequent analyses were conducted on data uncorrected for null alleles.

A neighbour-joining dendrogram (NJ) based on pairwise Nei's $\left(D_{\mathrm{A}}\right)$ genetic distances (Nei et al., 1983) was constructed with POPULATIONS v.1.2.32 software (Langella, 1999). Confidence estimates of tree topology were calculated by 1000 bootstrap replicates of loci. A NJ tree was drawn and visualized using Seaview v.4.4.3 (Gouy et al., 2010). Population structure was analysed using the Bayesian model-based clustering approach implemented in STRUCTURE v.2.3.4 (Pritchard et al., 2000). Fifteen independent runs were made for $\mathrm{K}=1-8$, with each run consisting of a burn-in of $10^{5}$ Markov-chain Monte Carlo steps followed by $5 \times 10^{5}$ steps. Selection of the most likely number of genetic clusters $(\mathrm{K})$ was based on the second-order rate of change in probability between successive $\mathrm{K}$ values as described in Evanno et al. (2005) and implemented in STRUCTURE HAR VESTER (Earl and von Holdt, 2012). Values from different run replicates under $\mathrm{K}=3$ and $\mathrm{K}=6$ were combined with CLUMPP v.1.1.2 (Jakobsson and Rosenberg, 2007) followed by DISTRUCT v.1.1 (Rosenberg, 2004) to graphically display each individual's membership coefficients for each cluster. Tests for genetic variation within groups $\left(F_{\mathrm{ST}}\right)$, among populations within groups $\left(F_{\mathrm{SC}}\right)$ and among populations $\left(F_{\mathrm{CT}}\right)$ were conducted with Analysis of Molecular Variation (AMOVA) with ARLEQUIN v.3.5.1.3 (Excoffier and Lischer, 2010), where the groups corresponded to the most likely number of genetic clusters $(K=3$ and $K=6)$ identified in STRUCTURE analyses. The significance of F-statistics of the AMOVA was tested using 10000 permutations.

\section{RESULTS}

A summary of the microsatellite results is provided in Table 2. In total, 243 alleles were observed 


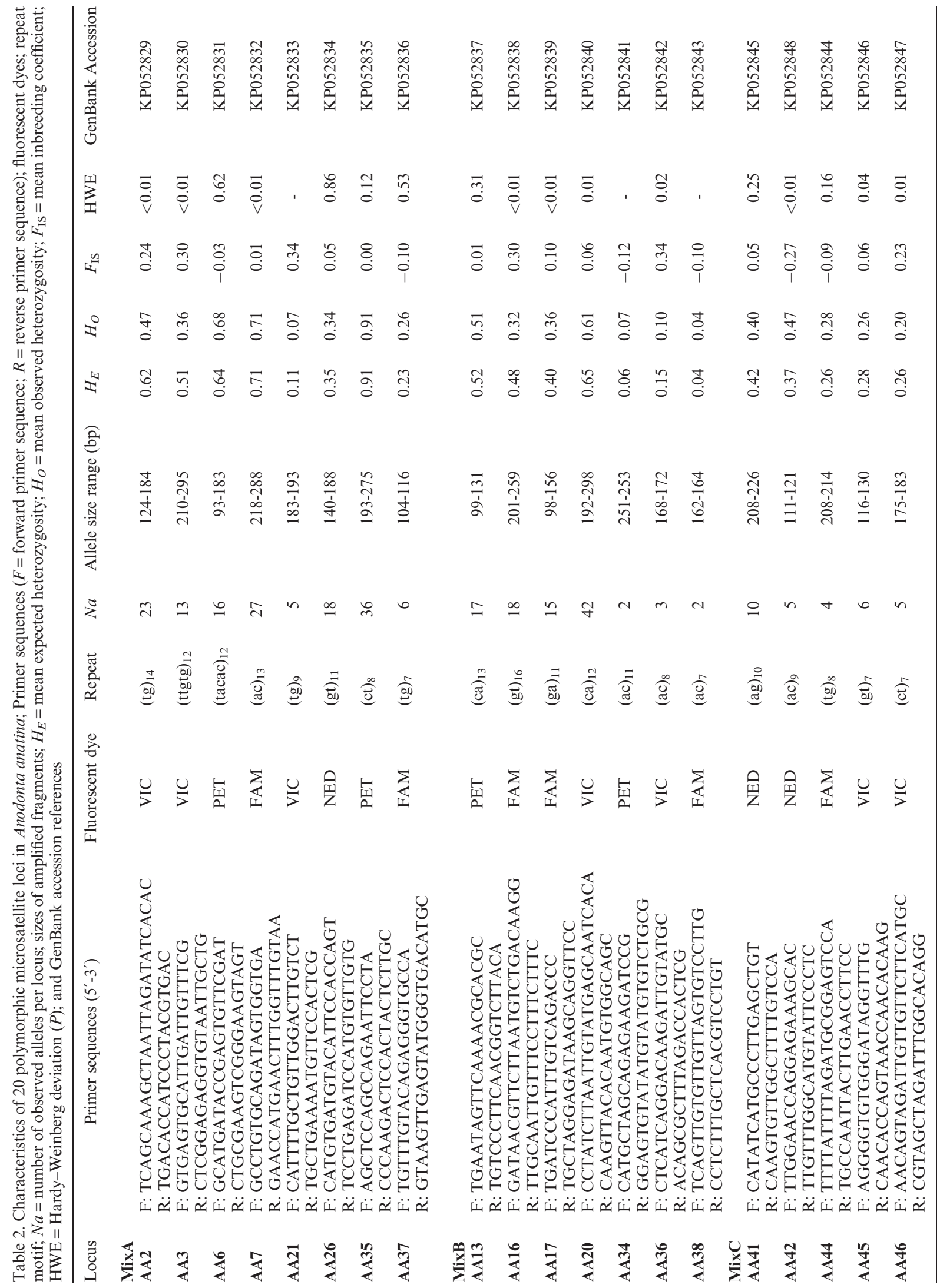


across the 20 loci, ranging from two (AA34, AA38) to 42 (AA20) alleles per locus. Six loci deviated from Hardy-Weinberg equilibrium, and significant inbreeding coefficients $\left(F_{\text {IS }}\right)$ ranged from 0.01 to 0.34 . Null alleles were detected in very few loci in very few populations (Table 3 ). However, the Reno population was an exception presenting null alleles in seven alleles. Curiously, one locus (AA6) failed to amplify on almost all individuals from the Ebro and Reno populations, which clustered together in the NJ tree (Figure 2). Nevertheless, this locus was not excluded from further analyses, as its removal affected neither the $F_{\mathrm{ST}}$ values nor the final population structure results (data not shown). Finally, linkage equilibrium was rejected for only one comparison (Medway; AA7/AA37) after Bonferroni correction (Holm, 1979), indicating that all loci could be considered as independent markers. Population microsatellite statistics are shown in Table 1; observed heterozygosity frequencies ranged from 0.05 (Douro) to 0.58 (Rhine), while expected heterozygosity frequencies ranged from 0.07 (Douro) to 0.58 (Rhine). The significant $F_{\text {IS }}$ inbreeding coefficients varied from -0.03 (Medway) to 0.38 (Douro). All pairwise $\mathrm{D}_{\text {est }}$-values (Table 4), and $F_{\mathrm{ST}}$-values were significant when corrected for multiple tests, these values indicating pronounced differentiation among all populations with the exception of Medway and Rhine. Four well

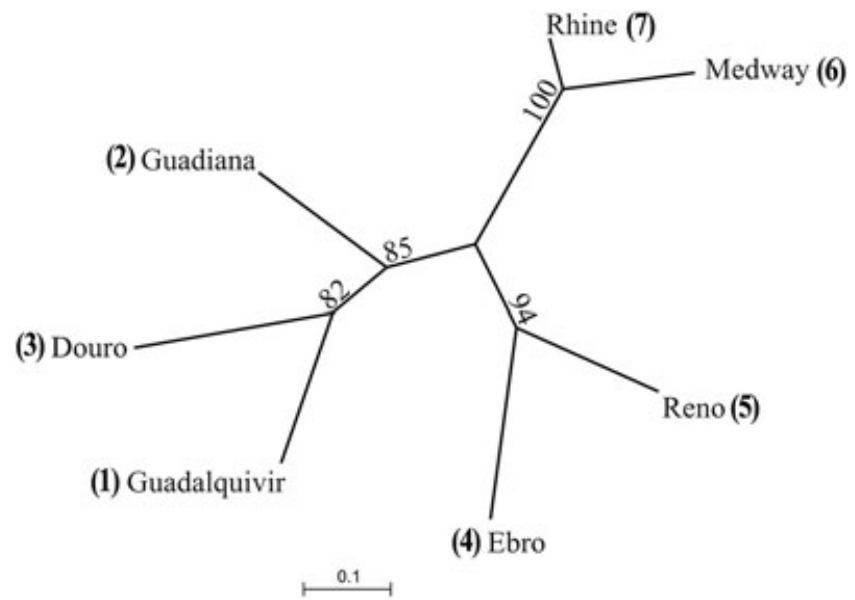

Figure 2. Neighbour-joining tree representing the Anodonta anatina populations analysed (bootstrap values above the branches).

supported groups are shown in the NJ tree (Figure 2); one with the Guadiana Basin, the second with the remaining Atlantic Iberian Basins (Douro and Guadalquivir), the third with the Ebro and Reno Basins and the fourth with Medway and Rhine Basins (Figure 2). The plots of $\Delta \mathrm{K}$ (Evanno et al., 2005) based on the STRUCTURE analysis indicated that three $(\mathrm{K}=3)$ is the most likely number of clusters present in the full dataset. Cluster one included the populations from Guadalquivir, Guadiana, and Douro, cluster two included the populations from Ebro and Reno and cluster three integrated the populations from

Table 3. Null allele frequencies for 20 microsatellite loci across all populations of Anodonta anatina. Null allele presences determined with MICROCHECKER (Van Oosterhout et al., 2004) are indicated in bold

\begin{tabular}{|c|c|c|c|c|c|c|c|}
\hline Locus & Guadalquivir & Guadiana & Douro & Ebro & Reno & Medway & Rhine \\
\hline AA3 & - & 0.36 & - & - & 0.15 & - & 0.12 \\
\hline AA7 & - & - & - & - & - & - & - \\
\hline AA13 & - & - & - & - & - & - & - \\
\hline AA16 & - & - & 0.20 & - & 0.39 & 0.13 & - \\
\hline AA17 & - & - & - & - & 0.26 & - & - \\
\hline AA26 & - & - & - & - & - & - & - \\
\hline AA34 & - & - & - & - & - & - & - \\
\hline AA35 & - & - & 0.15 & - & - & - & - \\
\hline AA36 & - & - & - & - & 0.19 & - & - \\
\hline AA 37 & - & - & - & - & - & - & - \\
\hline AA38 & - & - & - & - & - & - & - \\
\hline AA41 & - & 0.42 & - & - & - & - & - \\
\hline
\end{tabular}


Table 4. Pairwise estimates of $F_{\mathrm{ST}}$ (above diagonal) and Jost's $D_{\mathrm{EST}}$ (below diagonal) between all populations sampled for Anodonta anatina. All values are significant after sequential Bonferroni correction $(P<0.003)$

\begin{tabular}{lccccrrr}
\hline & Guadalquivir & Guadiana & Douro & Ebro & Reno & Medway & Rhine \\
\hline Guadalquivir & & 0.408 & 0.550 & 0.551 & 0.411 & 0.464 \\
Guadiana & 0.293 & 0.264 & 0.613 & 0.611 & 0.394 & 0.444 \\
Douro & 0.219 & 0.434 & 0.597 & 0.808 & 0.637 & 0.661 \\
Ebro & 0.418 & 0.480 & 0.581 & 0.293 & 0.352 & 0.492 \\
Reno & 0.545 & 0.539 & 0.763 & 0.551 & 0.645 & 0.350 \\
Medway & 0.714 & 0.410 & 0.686 & 0.548 & 0.597 & 0.448 \\
Rhine & 0.605 & & & & 0.079 \\
\hline
\end{tabular}

Medway and Rhine (Figure 3(A)). With the second most likely number of clusters $(K=6)$, each of the clusters, one to five, included only one population, while cluster six included the Medway and Rhine populations (Figure 3(B)). The results from AMOVA for $\mathrm{K}=3$ showed that $25 \%$ of the genetic variation was explained by differences among groups with high and significant $F_{\mathrm{ST}}$-values. Furthermore, the AMOVA results for $\mathrm{K}=6$ still explain $41 \%$ of the variation among groups, also with high and significant $F_{\mathrm{ST}}$-values.

\section{DISCUSSION}

The 20 microsatellite markers developed here resulted in successful amplifications of divergent populations of $A$. anatina across a wide geographical range.

A high level of population structure was found among all populations, but with considerable similarity between the populations in Central Europe (Rhine, Germany) and the British Isles (Medway, United Kingdom). The levels of differentiation among populations found in the present study are also congruent with the previously published mtDNA lineages (Froufe et al., 2014). Three distinct ESUs are proposed in the present study together with three MUs that should be managed independently.

\section{Population genetics}

The significant deviations from HWE detected in some loci have been commonly reported for Unionoid mussels (Eackles and King, 2002; Jones et al., 2006; Zanatta and Murphy, 2006). Possible explanations include the effect of null alleles, recent population bottlenecks or significant levels of close inbreeding, which may arise because of hermaphroditic reproduction known to occur in some populations of $A$. anatina (Hinzmann et al.,

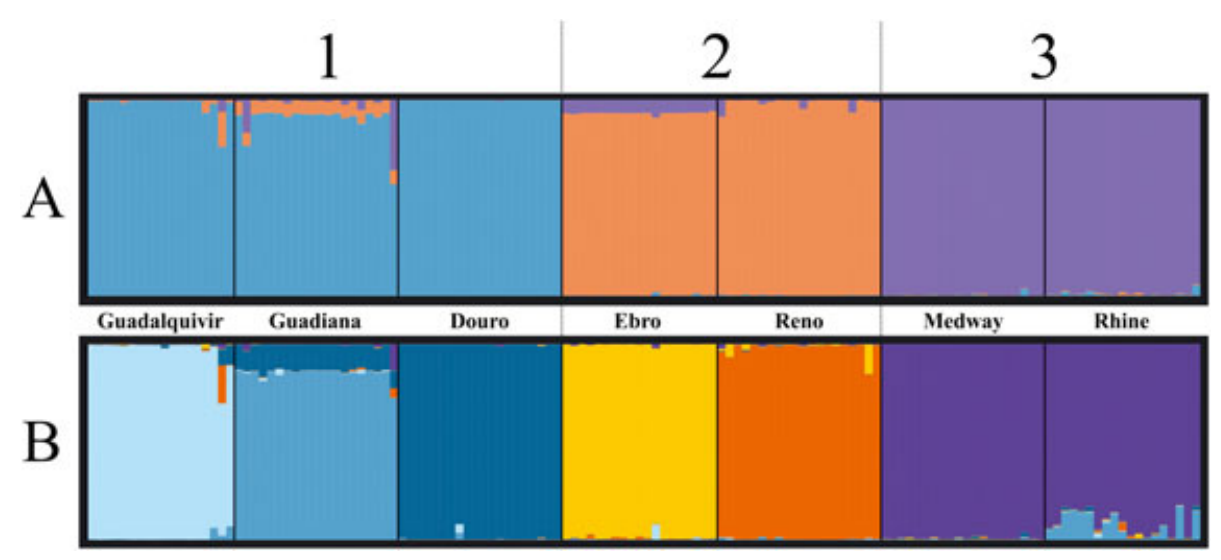

Figure 3. Results of the STRUCTURE Bayesian clustering analysis on Anodonta anatina populations: (A) with the most likely number of clusters $(\mathrm{K}=3)$; (B) with the second most likely number of clusters $(\mathrm{K}=6)$. Each individual is represented by a vertical bar in $\mathrm{K}$ coloured segments with the length of each bar being proportional to the estimated membership coefficient. Black lines separate individuals from different geographic regions. Numbers over the graphics correspond to the main mtDNA clades proposed by Froufe et al. (2014): 1 - Atlantic Iberian clade, 2 - Ebro + Italian clade; and 3 - Central European clade. 
2013). Since the primers were developed using DNA from animals from the Iberian clade, the number of null alleles in the Italian lineage (Ebro + Reno) might be related to the high genetic divergence of the Italian from the Iberian lineage with probable changes in the flanking region. The Douro and Reno populations had high $F_{\text {IS }}$ values. In the case of the Reno population, this can be attributed to founder effects since it is a very recent (1951) small lake created by a natural landslide. As for the Douro population, the high $F_{\text {IS }}$ values could be caused by the declining population resulting from recent bottlenecks due to human activities such as dam construction (Sousa et al., 2012).

\section{Relatedness of populations}

The most likely number of clusters from the Bayesian assignment and AMOVA analysis indicates a strong genetic structure among the studied $A$. anatina populations corresponding to the pattern previously found with mtDNA markers. One group includes all Atlantic Iberian basins (Gudalquivir, Guadiana and Douro), a second includes the Mediterranean Iberian (Ebro) and Italian (Reno) populations, and a third integrates the British (Medway) and German (Rhine) populations. Substructure of the Iberian populations is also confirmed with the Bayesian, AMOVA and NJ analysis. The pairwise $F_{\mathrm{ST}} / D_{\mathrm{EST}}$ comparison generated some of the highest values of genetic differentiation found so far for freshwater mussels (Zanatta and Murphy, 2007; Zanatta and Wilson, 2011). Although populations of $M$. margaritifera (family Margaritiferidae) in Central Europe have comparably high levels of differentiation, in the family Unionidae this highly structured pattern is only equivalent to those of the congeneric species $A$. californiensis/nuttalliana in the western US $\left(D_{\mathrm{EST}}=0.610\right.$ among all populations; Mock et al., 2010).

\section{Correspondence with mtDNA analysis}

In the present study, the high values of genetic differentiation among the populations belonging to the previously detected mtDNA lineages (Froufe et al., 2014) are congruent with an ancient divergence event. In addition, the results from the
NJ tree, with four supported clades, confirm the existence of genetic substructure in the Iberian populations. On the other hand, the mtDNA analysis has found no evident genetic structure in northern, central and eastern Europe from the British Isles through Germany and Poland all the way to Ukraine, including the Scandinavian countries. Similarly, a lower genetic differentiation between Medway (UK) and Rhine (Germany) populations was detected in this study using the new microsatellite markers. By contrast, in Germany a distinct pattern was found for the freshwater mussel M. margaritifera with highly differentiated populations among central European drainages (Geist et al., 2010a). Although the present study only analysed two $A$. anatina populations belonging to the northern European mtDNA clade, a probable explanation for the divergent pattern between the two species might be related to the fact that while Margaritifera spp. have a very narrow range of habitat preference and host fish for dispersal, Anodonta spp. may use a wide range of hosts and are able to occupy habitats subjected to different abiotic conditions. These features could significantly increase the dispersal ability and colonization success of $A$. anatina (Douda et al., 2013; Mock et al., 2013).

\section{Conservation implications}

Based on the present nuclear data, the previously identified mtDNA lineages of A. anatina (Froufe et al., 2014) are proposed here as three distinct evolutionarily significant units (ESUs) since they are geographically and historically separated, being reciprocally monophyletic for mtDNA haplotypes and showing, at the same time, significant divergence of allele frequencies at the nuclear loci (Moritz, 1994; Palsbøll et al., 2007; Frankham, 2010). Furthermore, all the southern European populations analysed can be defined as distinct management units since they present a high among-population differentiation, mainly at nuclear loci (Hedrick et al., 2001; Caballero et al., 2012).

Although more populations are needed to gain a fully comprehensive picture across the whole range of $A$. anatina, the populations from the British 
Isles, and central and northern Europe can be viewed as belonging to the same ESU. This ESU has a wide range and is therefore considered to have a more favourable conservation status than those from Southern Europe, which are more limited in distribution. Even so, considerable declines in spatial distribution and density of $A$. anatina have been recorded in some central European countries owing to pollution and habitat modification (Lopes-Lima, 2014), which means that this ESU will require monitoring. The ESU that includes the Italian and Ebro populations is mainly threatened by habitat degradation, water abstraction and invasive species and is declining rapidly (Cianfanelli et al., 2007; Halcon, 2011). As for the Atlantic Iberian ESUs, the Guadiana and Guadalquivir MUs on the south of the Peninsula are affected by historic mining pollution and more recent human impacts such as dam construction, urban development and agriculture (Company et al., 2008). Water shortage in some of the temporary streams of this ESU is possibly the most acute threat to this and other aquatic species. In the Douro MU the A. anatina populations are affected mainly by dam construction and pollution (Sousa et al., 2012).

All of the ESUs and MUs identified in this study deserve independent management attention. The genetic differentiation and divergence between ESUs should be considered in any study involving the physiology and toxicology of these animals. Distinct physiological traits such as host fish requirements, temperature resistance and other local adaptation characteristics should be assessed individually in each ESU. Furthermore, captive breeding programmes that aim to release or reintroduce $A$. anatina into natural habitats, should take account of specific genetic stocks with respect to the original genetic differentiation among the MUs detected in this study.

Unionoid populations are decreasing at an alarming pace, having been severely affected by many human activities that have resulted in habitat loss and fragmentation, pollution, overexploitation of resources, climate change and introduction of invasive species (Strayer et al., 2004; Lopes-Lima et al., 2014). Informed conservation strategies require high-resolution genetic analyses to identify populations with unique, divergent or low diversity (Geist et al., 2003). The microsatellites described here are valuable in fine-scale geographic studies and also provide a broadly useful set of tools for ecological and population genetic studies. For example, these markers may be applied to studies of dispersal rates (Berg et al., 2007), reproductive patterns such as identifying gamete dispersal and distance of reproduction (Ferguson et al., 2013), and the assessment of multipaternity, hermaphroditism and self-fertilization ratios (Bai et al., 2012). They also allow identification of co-evolutionary patterns, since these mussels have a parasitic larval phase in which they need a host fish for metamorphosis and dispersal (Geist and Kuehn, 2008; Zanatta and Wilson, 2011).

Throughout its range, $A$. anatina is exposed to increasing human pressure including increasing demands for water. This is especially pronounced in the Mediterranean biodiversity hotspot region (e.g. Portugal, Spain and Greece), which has severely impaired freshwater ecosystems, with a widespread decline and loss of endemic freshwater species (Albrecht et al., 2006; Benejam et al., 2010). Therefore, it is important to study patterns of genetic diversity of $A$. anatina in other biogeographical areas of southern Europe, such as the Balkans, Turkey or the Ponto-Caspian region, to assess whether they support further distinct and vulnerable ESUs. The microsatellite loci described in this study offer considerable utility in this respect.

\section{ACKNOWLEDGEMENTS}

We would like to thank our collaborators who have kindly provided us with tissue samples: Juergen Geist, Katharina Stoeckl, and Irene Guarneri. Financial support was provided by the Portuguese Foundation for Science and Technology (FCT) project PTDC/AAC-AMB/117688/2010. We would like to thank Susana Lopes for help with fragment analysis and acknowledge the assistance of staff at Genoscreen for generation of 454 sequence reads and DNA sequencing. Official capture and sampling licences were issued by Junta de Castilla y León (Consejería de Fomento 
y Medio Ambiente EP/CYL/331/2012, de 17 de Abril de 2012); Junta de Andalucia (Consejería de Medio Ambiente- SGYB/FOA/AFR/SFS, de 17 de Julio de 2012); and Gobierno de Aragón (Dirección General de Conservación del Medio Natural- 136.071/2012 de 12 de Julio de 2012).

\section{REFERENCES}

Albrecht C, Lohfink D, Schultheiss R. 2006. Dramatic decline and loss of mollusc diversity in long-lived lakes in Greece. Tentacle 14: 11-13.

Aldridge DC, Fayle TM, Jackson N. 2007. Freshwater mussel abundance predicts biodiversity in UK lowland rivers. Aquatic Conservation: Marine and Freshwater Ecosystems 17: 554-564.

Alves PC, Harris DJ, Melo-Ferreira J, Branco M, Suchentrunk F, Boursot P, Ferrand N. 2006. Hares on thin ice: introgression of mitochondrial DNA in hares and its implications for recent phylogenetic analyses. Molecular Phylogenetics and Evolution 40: 640-641.

Araujo R. 2013. Fauna Europaea. Version 2.6. Available at http://www.faunaeur.org/. Accessed 15.3.2014.

Bai Z, Luo M, Zhu W, Lin J, Wang G, Li J. 2012. Multiple paternity in the freshwater pearl mussel Hyriopsis cumingii (Lea, 1852). Journal of Molluscan Studies 78: 142-146.

Belkhir K, Borsa P, Chikhi L, Raufaste N, Bonhomme F. 2004. GENETIX 4.05, Population genetics software for Windows TM. Université de Montpellier II, Montpellier.

Benejam L, Angermeier PL, Munne A, García-Berthou E. 2010. Assessing effects of water abstraction on fish assemblages in Mediterranean streams. Freshwater Biology 55: 628-642.

Berg DJ, Christian AD, Guttman SI. 2007. Population genetic structure of three freshwater mussel (Unionidae) species within a small stream system: significant variation at local spatial scales. Freshwater Biology 52: 1427-1439.

Binot-Hafke M, Balzer S, Becker N, Gruttke H, Haupt H, Hofbauer N, Ludwig G, Matzke-Hajek G, Strauch M. 2011. Plants and fungi Volume 3, Invertebrates Part 1. In Red List of German Species, Bundesamt für Naturschutz: Bonn-Bad Godesberg, Germany.

Bogan AE. 2008. Global diversity of freshwater mussels (Mollusca, Bivalvia) in freshwater. Hydrobiologia 595: 139-147.

Bouza C, Castro J, Martínez P, Amaro R, Fernández C, Ondina P, Outeiro O, San ME. 2007. Threatened freshwater pearl mussel Margaritifera margaritifera L. in NW Spain: low and very structured genetic variation in southern peripheral populations assessed using microsatellite markers. Conservation Genetics 8: 937-948.

Byrne A, Moorkens EA, Anderson R, Killeen IJ, Regan EC. 2009. Ireland Red List No. 2 - Non-Marine Molluscs. National Parks and Wildlife Service, Department of the Environment, Heritage and Local Government: Dublin, Ireland.

Caballero S, Islas-Villanueva V, Tezanos-Pinto G, Duchene S, Delgado-Estrella A, Sanchez-Okrucky R, Mignucci-Giannoni AA. 2012. Phylogeography, genetic diversity and population structure of common bottlenose dolphins in the Wider Caribbean inferred from analyses of mitochondrial DNA control region sequences and microsatellite loci: conservation and management implications. Animal Conservation 15: 95-112.

Chapuis MP, Estoup A. 2007. Microsatellite null alleles and estimation of population differentiation. Molecular Biology and Evolution 24: 621-631.

Cianfanelli S, Lori E, Bodon M. 2007. Non-indigenous freshwater molluscs and their distribution in Italy. In Biological Invaders in Inland Waters: Profiles, Distribution, and Threats, Gherardi F (ed.). Springer: Dordrecht, The Netherlands; 103-121.

Company R, Serafim A, Lopes B, Cravo A, Shepherd TJ, Pearson G, Bebianno MJ. 2008. Using biochemical and isotope geochemistry to understand the environmental and public health implications of lead pollution in the lower Guadiana River, Iberia: a freshwater bivalve study. Science of the Total Environment 405: 109-119.

Crawford NG. 2010. SMOGD: software for the measurement of genetic diversity. Molecular Ecology Resources 10: 556-557.

Douda K, Lopes-Lima M, Hinzmann M, Machado J, Varandas S, Teixeira A, Sousa R. 2013. Biotic homogenization as a threat to native affiliate species: fish introductions dilute freshwater mussel's host resources. Diversity and Distributions 19: 933-942.

Eackles MS, King TL. 2002. Isolation and characterization of microsatellite loci in Lampsilis abrupta (Bivalvia: Unionidae) and cross-species amplification within the genus. Molecular Ecology Notes 2: 559-562.

Earl DA, von Holdt BM. 2012. STRUCTURE HARVESTER: a website and program for visualizing STRUCTURE output and implementing the Evanno method. Conservation Genetics Resources 4: 359-361.

Evanno G, Regnaut S, Goudet J. 2005. Detecting the number of clusters of individuals using the software STRUCTURE: a simulation study. Molecular Ecology 14: 2611-2620.

Excoffier L, Lischer HEL. 2010. Arlequin suite ver 3.5: a new series of programs to perform population genetics analyses under Linux and Windows. Molecular Ecology Resources 10: $564-567$.

Ferguson CD, Blum MJ, Raymer ML, Eackles MS, Krane DE. 2013. Population structure, multiple paternity, and longdistance transport of spermatozoa in the freshwater mussel Lampsilis cardium (Bivalvia: Unionidae). Freshwater Science 32: 267-282.

Frankham R. 2010. Challenges and opportunities of genetic approaches to biological conservation. Biological Conservation 143: 1919-1927.

Froufe E, Sobral C, Teixeira A, Lopes A, Sousa R, Varandas S, Lopes-Lima M. 2013. Development and multiplexing of microsatellite loci for the near threatened freshwater mussel Potomida littoralis (Cuvier, 1798) using 454 sequencing. Aquatic Conservation: Marine and Freshwater Ecosystems 23: 619-623.

Froufe E, Sobral C, Teixeira A, Sousa R, Varandas S, Aldridge DC, Lopes-Lima M. 2014. Genetic diversity of the pan-European freshwater mussel Anodonta anatina (Bivalvia: Unionoida) based on CO1: new phylogenetic insights and implications for conservation. Aquatic Conservation: Marine and Freshwater Ecosystems 24: $561-574$ 
Geist J, Kuehn R. 2005. Genetic diversity and differentiation of central European freshwater pearl mussel (Margaritifera margaritifera L.) populations: implications for conservation and management. Molecular Ecology 14: 425-439.

Geist J, Kuehn R. 2008. Host-parasite interactions in oligotrophic stream ecosystems: the roles of life-history strategy and ecological niche. Molecular Ecology 17: 997-1008.

Geist J, Rottmann O, Schröder W, Kühn R. 2003. Development of microsatellite markers for the endangered freshwater pearl mussel Margaritifera margaritifera L. (Bivalvia: Unionoidea). Molecular Ecology Notes 3: 444- 446.

Geist J, Söderberg H, Karlberg A, Kuehn R. 2010a. Drainage-independent genetic structure and high genetic diversity of endangered freshwater pearl mussels (Margaritifera margaritifera) in northern Europe. Conservation Genetics 11: 1339-1350.

Geist J, Geismar J, Kuehn R. 2010b. Isolation and characterization of the first microsatellite markers for the endangered swan mussel Anodonta cygnea L. (Bivalvia: Unionoidea). Conservation Genetics 11: 1103-1106.

Gómez A, Lunt DH. 2007. Refugia within refugia: patterns of phylogeographic concordance in the Iberian Peninsula. In Phylogeography of Southern European Refugia, Weiss S, Ferrand N (eds). Springer: Netherlands; 155-188.

Goudet J. 1995. FSTAT (version 1.2): a computer program to calculate F-statistics. Journal of Heredity 86: 485-486.

Gouy M, Guindon S, Gascuel O. 2010. SeaView version 4: a multiplatform graphical user interface for sequence alignment and phylogenetic tree building. Molecular Biology and Evolution 27: 221-224.

Graf DL. 2010. Funeral for the Nouvelle École-iana generic names introduced for freshwater mussels (Mollusca: Bivalvia: Unionoida). Proceedings of the Academy of Natural Sciences of Philadelphia 159: 1-23.

Gutiérrez JL, Jones CG, Strayer DL, Iribarne OO. 2003. Mollusks as ecosystem engineers: the role of shell production in aquatic habitats. Oikos 101: 79-90.

Haag WR. 2012. North American Freshwater Mussels: Natural History, Ecology, and Conservation, Cambridge University Press: Cambridge.

Halcon RMA. 2011. Bivalvos de agua dulce en la Delimitación Comarcal de Zaragoza. In Delimitación Comarcal de Zaragoza, Aragón IA, González, JLO (eds). Gobierno de Aragón: Zaragoza, Spain; 67-69.

Hedrick PW, Parker KM, Lee RN. 2001. Using microsatellite and $\mathrm{MHC}$ variation to identify species, ESUs, and MUs in the endangered Sonoran topminnow. Molecular Ecology 10: 1399-1412.

Hinzmann M, Lopes-Lima M, Teixeira A, Varandas S, Sousa R, Lopes A, Froufe E, Machado J. 2013. Reproductive cycle and strategy of Anodonta anatina (L., 1758): Notes on hermaphroditism. Journal of Experimental Zoology Part A: Ecological Genetics and Physiology 319: 378-390.

Holm S. 1979. A simple sequentially rejective multiple test procedure. Scandinavian Journal of Statistics 6: 65-70.

Jakobsson M, Rosenberg NA. 2007. CLUMPP: a cluster matching and permutation program for dealing with label switching and multimodality in analysis of population structure. Bioinformatics 23: 1801-1806.

Jones JW, Neves RJ, Ahlstedt SA, Hallerman EM. 2006. A holistic approach to taxonomic evaluation of two closely related endangered freshwater mussel species, the oyster mussel Epioblasma capsaeformis and tan riffleshell Epioblasma florentina walkeri (Bivalvia: Unionidae). Journal of Molluscan Studies 72: 267-283.

Jost L. 2008. $G_{\mathrm{ST}}$ and its relatives do not measure differentiation. Molecular Ecology 17: 4015-4026.

Langella O. 1999. POPULATIONS 1.2.32: Population genetic software. CNRS UPR9034. Available at: www. bioinformatics.org/ tryphon/populations.

Lopes-Lima M. 2014. Anodonta anatina. The IUCN Red List of Threatened Species. Version 2014.3. <www.iucnredlist. org $>$. Downloaded on 17 March 2015.

Lopes-Lima M, Teixeira A, Froufe E, Lopes A, Varandas S, Sousa R. 2014. Biology and conservation of freshwater bivalves: past, present and future perspectives. Hydrobiologia 735: 1-13.

Malausa T, Gilles A, Meglécz E, Blanquart H, Duthoy S, Costedoat C, Dubut V, Pech N, Castagnone-Sereno P, Délye C, et al. 2011. High-throughput microsatellite isolation through 454 GS-FLX Titanium pyrosequencing of enriched DNA libraries. Molecular Ecology Resources 11: 638-644.

Mock KE, Brim Box JC, Chong JP, Howard JK, Nez DA, Wolf D, Gardner RS. 2010. Genetic structuring in the freshwater mussel Anodonta corresponds with major hydrologic basins in the western United States. Molecular Ecology 19: 569-591.

Mock KE, Brim Box JC, Chong JP, Furnish J, Howard JK. 2013. Comparison of population genetic patterns in two widespread freshwater mussels with contrasting life histories in western North America. Molecular Ecology 22: 6060-6073.

Moritz C. 1994. Defining 'evolutionarily significant units' for conservation. Trends in Ecology and Evolution 9: 373-375.

Naimo TJ, Damschen ED, Rada RG, Monroe EM. 1998. Nonlethal evaluation of the physiological health of unionid mussels: methods for biopsy and glycogen analysis. Journal of the North American Benthological Society 17: 121-128.

Nei M, Tajima F, Tateno Y. 1983. Accuracy of estimated phylogenetic trees from molecular data. Journal of Molecular Evolution 19: 153-170.

Palsbøll PJ, Berube M, Allendorf FW. 2007. Identification of management units using population genetic data. Trends in Ecology and Evolution 22: 11-16.

Pritchard JK, Stephens M, Donnelly P. 2000. Inference of population structure using multilocus genotype data. Genetics 155: 945-959.

Raymond M, Rousset F. 1995. GENEPOP (version 1.2): population genetics software for exact tests and ecumenicism. Journal of Heredity 86: 248-249.

Reischütz A, Reischütz PL. 2007. Red List of the mollusks of Austria. In Red List of Endangered Animals in Austria, Zulka P (ed.). Grüne Reihe des BLFUW: Wien; 363-433.

Rosenberg NA. 2004. DISTRUCT: a program for the graphical display of population structure. Molecular Ecology Notes 4: 137-138.

Sambrook J, Fritsch EF, Maniatis T. 1989. Molecular Cloning: A Laboratory Manual, Cold Harbor Spring Press: New York.

Sárkány-Kiss A. 2003. Past and present status of the aquatic mollusk fauna in Transylvanian rivers. In Ecological Interpretation of Qualitative and Quantitative Dynamics, Proposals, Ujvárosi L (ed). Kolozsvár, Romenia: Sapientia Könyvek, Természettudomány; 107-150. 
Sell J, Mioduchowska M, Kaczmarczyk A, Szymańczak R. 2013. Identification and characterization of the first microsatellite loci for the thick-shelled river mussel Unio crassus (Bivalvia: Unionidae). Journal of Experimental Zoology Part A: Ecological Genetics and Physiology 319: $113-116$.

Sousa R, Varandas S, Cortes R, Teixeira A, Lopes-Lima M, Machado J, Guilhermino L. 2012. Massive die-offs of freshwater bivalves as resource pulses. Annales Limnologia - International. Journal of Limnology 48: 105-112.

Spooner DE, Frost PC, Hillebrand H, Arts MT, Puckrin O, Xenopoulos MA. 2013. Nutrient loading associated with agriculture land use dampens the importance of consumer-mediated niche construction. Ecology Letters 16: $1115-1125$.

Strayer DL, Caraco NF, Cole JJ, Findlay S, Pace ML. 1999. Transformation of freshwater ecosystems by bivalves. BioScience 49: 19-27.

Strayer DL, Downing JA, Haag WR, King TL, Layzer JB, Newton TJ, Nichols SJ. 2004. Changing perspectives on pearly mussels, North America's most imperiled animals. BioScience 54: 429-439.

Van Oosterhout C, Hutchinson WF, Wills DP, Shipley P. 2004. MICRO-CHECKER: software for identifying and correcting genotyping errors in microsatellite data. Molecular Ecology Notes 4: 535-538.

Vaughn CC, Hakenkamp CC. 2001. The functional role of burrowing bivalves in freshwater ecosystems. Freshwater Biology 46: 1431-1446.

Weir BS, Cockerham CC. 1984. Estimating F-statistics for the analysis of population structure. Evolution 38: 1358-1370.

Zanatta DT, Murphy RW. 2006. Development and characterization of microsatellite markers for the endangered northern riffleshell mussel Epioblasma torulosa rangiana (Bivalvia: Unionidae). Molecular Ecology Notes 6: 850-852.

Zanatta DT, Murphy RW. 2007. Range-wide population genetic analysis of the endangered northern riffleshell mussel, Epioblasma torulosa rangiana (Bivalvia: Unionoida). Conservation Genetics 8: 1393-1404.

Zanatta DT, Murphy RW. 2008. The phylogeographical and management implications of genetic population structure in the imperiled snuffbox mussel, Epioblasma triquetra (Bivalvia: Unionidae). Biological Journal of the Linnean Society 93: 371-384.

Zanatta DT, Wilson CC. 2011. Testing congruency of geographic and genetic population structure for a freshwater mussel (Bivalvia: Unionoida) and its host fish. Biological Journal of the Linnean Society 102: 669-685. 